\title{
BUDDHISM AND POLITICAL BEHAVIOUR
}

\author{
Dr. Ishwori Prasad Kandel
}

\begin{abstract}
The Buddha lived and taught 2.500 years before the field of psychology was established, but the teaching he left behind introduce wide-ranging and profound analysis of human behaviour that overlap. Buddhist Festivals are always joyful occasions. The most significant celebration takes place every May on the night of the full moon, when Buddhists all over the world celebrate the birth, enlightenment and death of the Buddha over 2,500 years ago. It has come to be known as Buddha Day. Buddhism, in its natural form, is not a religion; rather it is a tradition that focuses on personal spiritual development. The Buddha intended his philosophy to be a practical one, aimed at the happiness of all creatures. While he outlined his metaphysics, he did not expect anyone to accept this on faith but rather to verify the insights for themselves; his emphasis was always on seeing clearly and understanding. To achieve this, however, requires a disciplined life and a clear commitment to liberation; the Buddha laid out a clear path to the goal and also observations on how to live life wisely. The core of this teaching is contained in the Noble Eightfold Path, which covers the three essential areas of Buddhist practice: ethical conduct, mental discipline and wisdom. The goals are to cultivate both wisdom and compassion; then these qualities together will enable one ultimately to attain enlightenment.
\end{abstract}

Key Words : Enlightenment, Configuration, Disappoint, Innovative, Intervention, Attitude

\section{Introduction}

The word Buddha means "enlightened." The path to enlightenment is attained by utilizing morality, meditation and wisdom. Buddhists often meditate because they believe it helps awaken truth. There are many philosophies and interpretations within Buddhism, making it a tolerant and evolving religion. Some scholars don't recognize Buddhism as an organized religion, but rather, a "way of life" or a "spiritual tradition." Buddha's most important teachings, known as The Four Noble Truths, are essential to understanding the religion. There is no single Buddhist symbol, but a number of images have evolved that represent Buddhist beliefs, including the lotus flower, the eight-spoked dharma wheel, A gold Buddha figure at the Longhua Temple in the south of Shanghai, first built in 242 AD (

1 Associate Professor Central Department of Political Science, T.U. Kirtipur. 
https://www.history.com/topics/religion/buddhism). Siddhartha Gautama, later known as Buddha, was a prince of the Sakya tribe of Nepal in approximately $566 \mathrm{BC}$. At the age of 29, leaving the comforts of his home, he undertook a journey to seek the meaning of the suffering he saw around him. After six years of arduous yogic training, he abandoned the way of self-mortification and instead sat in mindful meditation beneath a bodhi tree (Wilson, (2010 p. 87). The Buddha wandered in the plains of north-eastern India for over four decades, teaching the path or Dharma he had realized in that moment. Around him developed a community or Sangha of monks and, later, nuns, drawn from various tribes and castes, devoted to practicing this path. In approximately $486 \mathrm{BC}$, at the age of 80 , the Buddha died. On the full moon day of May, Siddhartha Gautama became the Buddha, the enlightened one. (Weber, 2009, p. 168). His last words are said to be... "Impermanent are all created things; Strive on with awareness." In all districts of all lands, in all the classes of communities thousands of minds are intently occupied, the merchant in his Compting house, the mechanist over his plans, the statesman at his map, his treaty, \& his tariff, the scholar in the skilful history \& eloquence of antiquity, each stung to the quick with the desire of exalting himself to a hasty \& yet unfound height above the level of his peers. Each is absorbed in the prospect of good accruing to himself but each is no less contributing to the utmost of his ability to fix \& adorn human civilization (William, 1822-1826, p. 305).

\section{Buddhism History}

When Gautama passed away around 483 B.C., his followers began to organize a religious movement. Buddha's teachings became the foundation for what would develop into Buddhism. In the 3rd century B.C., Ashoka the Great, the Mauryan Indian emperor, made Buddhism the state religion of India. Buddhist monasteries were built, and missionary work was encouraged. Over the next few centuries, Buddhism began to spread beyond India. The thoughts and philosophies of Buddhists became diverse, with some followers interpreting ideas differently than others. In the sixth century, the Huns invaded India and destroyed hundreds of Buddhist monasteries, but the intruders were eventually driven out of the country. Islam began to spread quickly in the region during the Middle Ages, forcing Buddhism into the background. The first three substantive offer rich descriptions of the key and arguments of Buddhism, along with a very quick overview (White, 2005, $p$. 334). How Buddhist argumentation has changed during its period of "modernism" since the mid-nineteenth century. Its descriptions by way of surveying what it calls the "theory of government and political theory in early Buddhism." Moore notes that debate exists in the scholarly literature over the extent to which Buddhism supports or offers a place for politics in its theory, and whether that theory supports monarchism or more popular 
political decision-making. It narrates several short stories or fables from the early Pali canon - such as the story of Dalhanemi, a cakkavatti or "wheel-turning monarch," who advances Buddhist principles through his governance - to argue that Buddhism does possess a distinctive political theory (William, 1822-1826, p. 205). Among its criteria for good governance is included a theory of legitimacy, which, according to Moore, "is not about adequately respecting the autonomy of rational selves but rather about creating conditions to allow human beings to make spiritual progress" (p. 26). If Buddhism can be seen as a process of personal development, one may well ask: what is a person, if not a soul or self? In keeping with the ideas of dependent origination, Buddhism views a person as a changing configuration of five factors, or 'skandhas' (Mookergee, 2017, p. 312). First there is the world of physical form; the body and all material objects, including the sense organs. Second there is the factor of sensation or feeling; here are found the five senses as well as mind, which in Buddhism is considered a sense organ. The mind senses thoughts and ideas much the same as the eye senses light or the ear senses air pressure. Thirdly, there is the factor of perception; here is the faculty which recognizes physical and mental objects. Fourth there is the factor variously called impulses or mental formulations; here is volition and attention, the faculty of will, the force of habits. Lastly, there is the faculty of consciousness or awareness. In Buddhism consciousness is not something apart from the other factors, but rather interacting with them and dependent on them for its existence; there is no arising of consciousness without conditions. Here we see no idea of personhood as constancy, but rather a fleeting, changing assortment or process of various interacting factors. In this readable book (William, 1822-1826, p. 275). Matthew J. Moore offers the resources for political theorists to see how their own familiar debates might intersect with, and even benefit from, Buddhist philosophy. Its synthetic approach, lucid writing, and short length suggest that this book would best serve as an undergraduate or graduate text for an introductory course in political theory, rather than as a research monograph advancing a new argument within Buddhist philosophy. The content and organization of the book, described by Moore in his short introduction as a "roadmap for other scholars interested in Buddhism" (p. 3), bears out this supposition (Matthew, 2018, p. 54), Similarly offers schematic, short descriptions of key texts to show that for most Buddhists before the nineteenth century, monarchy was the central political system they endorsed. However, Moore goes on to show that this widely shared assumption about the basic feature of Buddhist political society changed rapidly, starting in the 1850 s, when Buddhists began harnessing different interpretations to justify democratic change among themselves. 
The features a dizzying survey of Buddhist modernism in all the world's Buddhist-majority countries, including Bhutan, Thailand, and Tibet, each of which receives about two pages of brief treatment, which functions mostly as a summary provide the "meat" of Moore's main interpretive point, which present mainly historic exposition and a survey of the key secondary debates on Buddhism (White,2005, p. 214). . Some of the Buddhist texts in relation to concepts and arguments from Western political theory. Moore's claim "that Buddhist political theory rests on three underlying ideas that simultaneously are familiar to Western thinkers and represent positions that almost no Western thinkers have been willing to embrace," namely, the denial of an existence of the self, the emphasis on the relative lack of importance of politics in human life, and an ethics that is both naturalistic (Matthew, 2018, p. 53). There are three general waves of Buddhism. One went to Southeast Asia, the so called Theravada Buddhism. We find that in Sri Lanka, Burma, Thailand, Laos and Cambodia, a little bit in Vietnam. And then we find one wave went through Central Asia to China, and from China to Japan and Korea, and down to Vietnam. And then another wave that went later from India to Tibet, and from Tibet to Mongolia, and throughout Central Asia and to the various Mongol groups who came to Russia, so the Buryats, the Kalmyks and also a Turkic group - the Tuvinians. So we have a wide diversity, and that is a bit simplifying, because within that there were various waves (Alexander, 2012, p. 34). The Buddhist theory of no-self, which offers more details than the introduction's survey of the same material. Buddhism into a broader discussion of what the author calls "theories of limited citizenship, East and West" although it is worth noting that despite the rich examples drawn from the "West" side of that binary, Buddhism is the only theory drawn from the "East" (William, 1822-1826, p. 311). While this discussion is fascinating in itself, the distinctive contribution of Buddhist ideas here is less than clear; the book spends only four pages discussing Buddhist theories of politics, repeating the basic points made in the introductory section (Suzuki, 2017, p. 61). On the one hand, given this relative lack of deep engagement on this point, the reader wonders if the analysis of limited citizenship could proceed equally well without mentioning Buddhism at all. Buddhism in acknowledging politics as an inevitable and even often beneficial feature of the human condition, while also privileging other commitments as more important than politics (Weber, 2009, p. 214). The examines the Buddhist denial of the self in relation to Nietzsche's similar claim about "under-souls," and argues that ultimately Buddha's theory is preferable "even when assessed using. Moore argues that only the Buddha's insistence on abandoning a persistent self offers a way out of Nietszchean existential resentment, even from Nietzsche's point of view; and moreover that, contra Nietzsche and some of his contemporary interpreters, it is capable to live as human with normative goals even without the persistent self (pp. 80-81). 
It goes on to explain Nietzsche's theory of the self and argues that the real divergence between the two lies not in their description of the self but in their attitude toward the self's multiplicity and seeming lack of metaphysical center (p. 75). On the other hand, however, Moore here does pursue a strategy for de-eroticizing Buddhism by assimilating it to existing political theory ideas.

He became a wandering ascetic, practiced yogic disciplines and meditation, studied with various teachers, and attained high states of consciousness; but still he did not find the answer to his question. He practiced severe forms of asceticism, almost to the point of death by starvation, all without gain. Finally he sat under a bodhi tree, determined not to rise from meditation until he had gained the insight he sought. Not long after, he attained enlightenment; he became the Buddha the Awakened One (Mookergee, 2017, p. 312). He had ascended through various stages of meditative awareness, he had seen all of his past lives, and he had seen directly into reality, into the nature of existence and the causes of suffering and rebirth. He pondered whether to try to teach these insights, so subtle and difficult to grasp to others; perhaps it would be futile. But finally he decided that at least some of the people would be able to understand; perhaps more importantly, they could be shown the path to arrive at these insights themselves (Wilson, (2010 p. 97). He gave his first sermon to a few disciples in the Deer park at Benares, and then continued to wander and teach for the next forty-five years, until his death at the age of eighty (Weber, 2009, p. 204). Moore further argues, Buddhist ethics can tie more closely to an existing tradition in Western thought of immanence politics, today associated with such contemporary thinkers as William. Buddhist philosophy is richly synthetic, offering a very clear overview of existing Anglophone debates (White,2005, p. 204). Buddhist ethics and meta-ethics while drawing in contemporary political theory discussions about the conditions of ethical plurality and appropriate responses to it turns to an explicit examination of Buddhist ethics, which historically have received much greater attention from philosophers than have Buddhist theories of politics. Buddhism is not major religions, although one wonders why Buddhism is described necessarily as a religion rather than a philosophy, and what is at stake in that description, has a "hypothetical" approach to ethics: that is, it offers what it takes to be good advice about how one should act, rather than articulating a series of moral duties that derive from absolute claims about the good. By avoiding appeals to the supernatural, It's exploring each facet of Moore's interpretation of Buddhism in relation to political theory, each making an independent point rather than building cumulatively to a larger argument (William, 18221826 , p. 125). Along with the long introductory section - which comprises nearly half the lack of a singular argumentative thread suggests. Buddhism or to comparative political 
theorists who already possess basic knowledge of Buddhist ideas (Suzuki, 2017, p. 57). The comprehensive set of English-language secondary literature on Buddhist thought, and carefully navigates its way through some key scholarly debates, such as about whether Buddhist ethics is hypothetical rather than categorical. But it does not use its chapters as stepping stones to a larger original intervention in those debates, which - given the relative lack of attention in political theory to this vitally important and globally, is somewhat unfortunate. Meanwhile, the photography and research of Buddhist sites in the other countries of Asia was taken up (Mookergee, 2017, p. 322). He was taken to Kashmir for thirteen years by his mother, where he learnt Sanskrit and studied Buddhist scriptures. On his return, he became the most famous translator of Buddl'Ht scriptures in Kucha. It is said that China attacked and annexed Kucha because of the importance of Kumarajiva. Today , there is a modern statue of Kumarajiva in front of the Kizil Caves. The art of the caves displays the influences coming from India (Beney, 2018, p. 65). Research fellowships very kindly given to me by the Maulana Abul Kalam And Institute of Asian Studies made it possible for me to explore and document the northern spread of Buddhism from the Indian sub-continent (Beney, 2018, p. 65). This was the spot from where King Yeshe Od directed the construction of a legendary chain of 108 monasteries, across Western Tibet, Ladakh, LahauleSpiti and Kinnaur. The making of the monasteries was supervised by the Great Translator Lhotsava Rinchen Zangpo. The paintings and sculptures inside the monasteries were made by artists who were invited from Kashmir for the purpose. This is among the greatest bodies of the art of mankind (White,2005, p. 134). It is full of lyrical grace and joy. The exquisite paintings are also of special value, as those which were made in the valley of Kashmir in the ancient period have all been lost (Beney, 2018, p. 55). More discussion of how Buddhist ideas might be presented on their own terms, in ways that challenge or displace the commitments of the field, would have been welcome. Connolly's immanence politics offers one direction that Buddhism could go in developing a more adequate political theory for modernity. This is a tantalizing suggestion, and one that a reader might reasonably expect a book calling itself "Buddhism and Political Theory" to undertake. Unfortunately, very little of this kind of further development is on view (https:// www.history.com/topics/religion/buddhism). The knowledge of Buddhism to political theorists and students who may not otherwise encounter it. But those readers looking for an innovative intervention into the existing debates in Buddhist philosophy will likely be disappointed (Mookergee, 2017, p. 312). The main principles of Buddhism are covered by the teachings in the form of 'The Three Jewels', 'The Four Noble Truths', 'The Noble Eightfold Path', 'The Five Precepts', 'The Three Marks of Conditioned Existence' and 'Vegetarianism'. The most important ones are described below. Triple Jewels: Taking 
refuge in The Triple Jewels/Gems, i.e. the Buddha, the Dharma and the Sangha; does not mean self-surrender, or total reliance on an external force, or third party for help or salvation (Wilson, (2010 p. 89). The Four Nobel Truths: The foundation of Buddhism is centered on the Four Noble Truths given by Buddha in his first sermon after his enlightenment (Beney, 2018, p. 55). The truths are: Dukkha - The Truth of Suffering, Samudaya - The Truth of the Cause of Suffering, Nirhodha - The Truth of the End of Suffering, and Magga - The Truth of the Path that frees us from Suffering The Eightfold Path to Enlightenment: Buddhism lays stress on 'The Eightfold Path' as means by which enlightenment may be realized (Suzuki, 2017, p. 55). This was explained by the Buddha in his first sermon after his enlightenment, preserved in the 'Dhammacakkappavattana Sutta'. Followers point to three main sections within 'The Eightfold Path' as Wisdom, Ethical Conduct and Mental Discipline.“..There is a path to the cessation of suffering, the 'eightfold path' of right views, right resolve, right speech, right action, right livelihood, right effort, right mindfulness, and right concentration (Beney, 2018, p. 65). Buddhism characteristically describes reality in terms of process and relation rather than entity or substance." What is, however, particularly refreshing in this tense atmosphere of fighting is the fact of the earnestness of the fighters. Though all cannot be regarded as equally honest or honourable in their methods, their earnestness and sincerity are beyond doubt or cavil. The fighting has all the freshness of life and reality. There is no air of unreality about it. In fact, they fought for what they believed to be a question of life and death. Philosophy was not a matter of academic interest in India. Change of philosophy meant the change of entire outlook and orientation in life. Victory in a philosophical debate, therefore, was essential to the preservation of one's religion and mode of life, and defeat spelt inglorious death or apostacy from the accepted faith. There was, in fact, no line of demarcation between philosophy and religion in India (White,2005, p. 234). A religion without a philosophical backing was unthinkable (Mookergee, 2017, p. 342). A few facts are to be mentioned concerning the matter treated in this Series, which have come up while it was in the press. The Tun-huang MS. of the Sayings of Shén-hui mentioned has already been re- produced in facsimile, while its printed and fully revised edition will be published before long (Wilson, (2010 p. 87). He supplies us with a wealth of useful information regarding them. All page references to the Gandavyitha are either to the Idzumi MS. or to the R.A.S. one. Quite likely it is the 'older edition' referred to in a preface to the current edition of the Tan-ching. Its historical importance is beyond dispute (Suzuki, 2017, p. 65) . 


\section{Conclusion}

Buddhism is profound, superb and wonderful. However, it is very much distorted and misinterpreted. The common misconception is held by a great many people, that in the wake of advanced development of science today, Buddhism, which promotes superstition. On the other hand, some other people cherish the notion that insofar as Buddhism is established on theological basis, it is not without a good measure of spiritual value to humanity. Whereas the criticism of Group A show sheer ignorance of Buddhism, apparently, the remark of is paradoxical. In view of these misconceptions, the writer therefore presented his understanding of Buddhism based on direct perception from the scientific point of view. To Group A he would like to say that Buddhism is not only devoid of superstition, but on the contrary, is the best cure for every superstition in our world, because its Teaching is absolutely logical, impartial and rational, he would say that Buddhism is neither a theological religion nor a neurothesia for mental ills, but a Subject of Study, similar to science, to probe into the truths of life and the universe; apart from its extraordinary functions and extensive application, it is a wholesome, practical Way of Living to be realized by self experiencing only. From the preceding chapters, it may summed up that as a religion, Buddhism is based on absolute freedom and true equality; it is rational, liberal, objective, concrete, complete, positive, pragmatic and applicable at all levels. As a token of the writer" profound gratitude, this page is most sincerely and respectfully presented; may it gladden all those who have read it, enhance their faith and fortify their resolution to live up to the Buddhist Way of Life. So, what is the future of that? Will it become as widespread as Christianity? I do not think so! I think that, first of all, obviously, I am certainly not an expert in the situation of the Orthodox church here in Russia, but from what people tell me, it is struggling in terms of getting the interest of young people. Will young people be more interested in Buddhism? I do not know. I think a lot depends on how it is presented. If it is presented in this magical type of way, I do not see any great benefit from that, because often what happens is that they imagine and hope that they will get a magic cure, and then they do not, because nothing follows from that. And so, this is not so helpful. If the situation becomes more and more desperate, then more and more people may turn for an exotic type of cure, but I do not know how stable that will be (Alexander, 2012, p. 44). For more than two millennia, Buddhism has been a powerful religious, political, and social force, first in Nepal, its original homeland, and then in many other lands. It remains a powerful religious, political, and cultural force in many parts of the world today. There is every reason to expect that the appeal of Buddhism will continue far on into the future. Buddha's teachings are known as "dharma." He taught that wisdom, kindness, patience, generosity and compassion were important virtues. Specifically, all Buddhists live by five moral precepts, which prohibit: Killing living things, Taking what is not given. Sexual misconduct, Lying and Using drugs or alcohol. 


\section{Reference}

Behik, Beney (2018), Buddhism The Path of Compassion, (hardcover edi. 2018), India : Publication Division Ministry I and B,

Berzin, Alexander (2012), The challenge for Buddhism in the $21^{\text {st }}$ century, Russia : State institute for international relations.

Dowman, Keith (2020), Masters of Mahamudra (paperbook edi, 2020), India : Dev Publisher and Dietributer.

Goenka, S.N.(2012), Was The Buddha a Pessimist? (paperbook edit. 2012), India : Vipassand Research Institute.

Matthew J. Moore (2018), Contemporary Political Theory (volume 17), London: Oxford University Press, p. 55-58.

Mookeragee, Satkari (2017), The Buddhist Philosophy of Universal Flux, (hardcover edi. 2017), India : Motial Banarsidates Publisher,

Suzuki, D.I. (2017), Eassys in Buddhism (Third Series), paperback edi. 2017), India : New Age Books,

Weber, Max (2009), The Religion of India, (hardcover edi.. 2009), India : Radha Publications. William H. Gilman (1822-1826), The Journals and Miscellaneous Notebooks (vole, II), India: Ralph Waldo Emerson p. 305

White, Kenneth (2005), The Role of Bodhicitta in Buddhist Enlightenment Including a Translation into English of Bodhicitta-sastra, Benkemmitsu-nikyoron, and Sammaya-kaijo, London: The Edwin Mellen Press.

Wilson, Jeff (2010), Sasāra and Rebirth, in Buddhism, London : Oxford University Press.

Citation Information

History.com Editors

Website Name

HISTORY

URL

https://www.history.com/topics/religion/buddhism

Access Date

February 28, 2020

Publisher

Original Published Date

October 12, 2017 